$\begin{array}{llr}\text { KULTURA } & \begin{array}{l}\text { POLSKA A KADEMIA NAUK } \\ \text { KOMITET SOCJOLOGII }\end{array} & \begin{array}{r}\text { ISSN 0023-5172 } \\ 2300-195 \mathrm{x}\end{array} \\ \mathbf{\text { I }} & \begin{array}{l}\text { INSTYTUT STUDIÓW POLITYCZNYCH } \\ \text { SPOLECENSTWO }\end{array} & \\ 2020, \text { nr 1 SWOI I OBCY. KULTURA GOŚCINY } & \end{array}$
$\begin{array}{lllllllllllllll}A & R & T & Y & K & U & 亡 & Y\end{array}$
I
$\begin{array}{llllllll}\mathrm{R} & \mathrm{O} & \mathrm{Z} & \mathrm{P} & \mathrm{R} & \mathrm{A} & \mathrm{W} & \mathrm{Y}\end{array}$

MAŁGORZATA KOSTRZYŃSKA

Uniwersytet Łódzki

\title{
PRACA INTERAKCYJNA NAD TOŻSAMOŚCIĄ DRUGIEGO, CZYLI O TAKTYKACH WZAJEMNEGO „WYCHOWYWANIA SIĘ” PRZEZ OSOBY DOŚWIADCZAJĄCE BEZDOMNOŚCI
}

\section{WPROWADZENIE}

Jest to cząstkowy raport $z$ badań etnograficznych, przeprowadzonych przeze mnie wśród mężczyzn doświadczających bezdomności, przebywających $w$ hostelu utworzonym przez pewne stowarzyszenie ${ }^{1}$. Ich cel stanowiła rekonstrukcja interakcyjnej pracy nad tożsamością drugiego. Zagadnienia ogniskujące podjętą problematykę to: praca nad tożsamością i proces stowarzyszania się, w toku którego owa praca przebiega. Rekonstruowana praca nad tożsamością podejmowana jest przez osoby doświadczające bezdomności - uczestników badania, dlatego zjawisko bezdomności pełni w prezentowanej analizie istotną rolę. Na uwagę zasługuje także specyfika badanego hostelu, utworzonego w opozycji do schronisk im. Brata Alberta. Wszystkie te zagadnienia, powiązane ze sobą, budują-

Adres do korespondencji: malgorzata.kostrzynska@uni.lodz.pl; ORCID: 0000-0003$-3635-9771$

${ }^{1}$ Było to badanie partycypacyjne, którego uczestnikami byli mężczyźni doświadczający bezdomności, współpracujący w ramach powołanego przez siebie stowarzyszenia, przebywający w prowadzonym przez to stowarzyszenie hostelu. Badanie to prowadziłam w latach 2007-2013 (z krótką przerwą) jako asystent w Katedrze Pedagogiki Społecznej Uniwersytetu Łódzkiego. 
ce specyfikę eksplorowanej rzeczywistości, opisuję tu szczegółowo w celu lepszego zrozumienia przedmiotu analizy.

Specyfika objętego badaniem stowarzyszenia

Badania przeprowadziłam w dużym mieście wśród członków stowarzyszenia powołanego przez grupę bezdomnych mężczyzn. Ze względu na skoncentrowanie działań podejmowanych przez to stowarzyszenie wokół prowadzenia hostelu dla bezdomnych, a więc niejako utożsamienie stowarzyszenia $z$ hostelem, teren badań objął w większości jego mieszkańców (jednocześnie członków stowarzyszenia) (w czasie rozpoczęcia badania przebywało w nim 13 bezdomnych mężczyzn, a w czasie zakończenia 20), a także osoby spoza - reprezentantów świata „domnych” — zrzeszonych we wspólnie prowadzonej organizacji. W miarę upływu czasu do badania byli włączani nowi mieszkańcy, a z uczestnikami badania, którzy $z$ różnych przyczyn rezygnowali z pobytu w hostelu, starałam się utrzymać kontakt. Na podobnych zasadach włączałam do badania także „domnych” członków organizacji. Dodatkowo badaniem objęłam przestrzenie życia społecznego interakcyjnie „zagospodarowywane” przez jego uczestników, wyznaczane zakresem codziennych działań podejmowanych przez członków stowarzyszenia ${ }^{2}$.

Warto podkreślić, że specyfika badanego hostelu zdecydowanie wyróżnia go spośród innych schronisk czy noclegowni dla bezdomnych. Charakteryzujący go uczestnicy badania, żyjący w tym hostelu, mówią o: niewielkiej liczbie mieszkańców umożliwiającej im poczucie prywatności, wzajemnym wsparciu czy szansie indywidualnej pracy nad zmianą sytuacji życiowej.

Stowarzyszenie to powstało $\mathrm{w}$ kosekwencji osobistego doświadczenia bezdomności. Jego inicjatorzy postanowili powołać do życia „własna przestrzeń” 3 . Budowali ją w wyraźnej opozycji do „popularnych” w Polsce

2 Sposób doboru próby w opisywanym badaniu odpowiada pojęciu teoretycznego doboru próby (theoretical sampling) (Glaser, Strauss 1967, s. 45); dążyłam w nim do teoretycznego nasycenia próby (theoretical saturation) (Charmaz 2009, s. 147-148).

${ }^{3} \mathrm{Na}$ wstępie powinnam przedstawić techniczną stronę porządkowania materiału badawczego. Przede wszystkim w celu oddania atmosfery zjawisk opisywanych przez uczestników badania w tekście wielokrotnie pojawiają się określenia zaczerpnięte bezpośrednio z ich języka potocznego (in vivo codes; zob. Strauss 2013); są opatrzone cudzysłowem i pisane kursywą, każdorazowo, niezależnie od liczby powtórzeń.

Szkielet teoretyczny zgromadzonego materiału w dużej mierze stanowią wykorzystywane przez uczestników badania strategie oraz taktyki działania (różnicę między strategią a taktyką wyjaśniam poniżej). W celu ich wyróżnienia, stosuję zapis spacją (w przypadku strategii) oraz zapis spacją dodatkowo wyróżniony kursywą (w przypadku taktyk). Za- 
schronisk im. Brata Alberta (określam je dalej za uczestnikami badania jako schroniska „Alberta”). Ich wcześniejszy pobyt w takim schronisku ma duże znaczenie dla procesu definiowania siebie w odniesieniu do innych bezdomnych. U uczestników badania widoczne jest bowiem budowanie tożsamości opozycyjnej, ujawniane poprzez nieustanne próby „odcinania się” od bezdomnych przebywających w schronisku „Alberta” oraz bezdomnych „ulicznych”, z wykorzystaniem tego kontekstu w celu wyraźniejszego zakreślenia nie tylko tożsamości osobowej konkretnych mieszkańców, ale i całego stowarzyszenia. Tym samym do hostelu trafiają przeważnie ci, którzy wciąż próbują podejmować działania na rzecz zmiany swojej sytuacji życiowej, są aktywni, zmotywowani do pracy. Wielu spośród nich doświadczyło krótszych, bądź dłuższych pobytów w schroniskach „Alberta”, skąd uciekli „w trosce o własna godność i przetrwanie”, jak sami mówią.

Na pytanie, czy mieszkańcy schroniska są, czy czują się i wreszcie czy sami definiują się w kategoriach osób bezdomnych, odpowiedź nie jest prosta. Jedno jest pewne - bezdomność stanowi niekiedy aktualne, a na pewno przeszłe, wspólne doświadczenie objętych badaniem.

\section{Teoretyczno-metodologiczna perspektywa badania}

Perspektywą oglądu eksplorowanej rzeczywistości stał się interakcjonizm symboliczny. W paradygmacie interpretatywnym teoria nie służy późniejszej weryfikacji, ale wskazuje obszar inspiracji teoretycznych, przyjmując postać pojęć „uczulających” (sensitising concepts) (Blumer 2007 [1969]). W opisywanym badaniu stały się nimi, przy czym inspiracje nasunął analizowany materiał, koncepcja(e) tożsamości w ujęciu interakcyjnym (Strauss 1969; Brittan 1977; Melchior 1990; Błeszyńska 2001; Bokszański 1989); koncepcja piętna Ervinga Goffmana (2005); bezdomność w ujęciu interakcyjnym (Wujcicka 2007).

Przedmiotem badania stał się proces stowarzyszania się w kontekście mieszanych sytuacji społecznych. Problem główny zarysowuje się w postaci dwóch pytań, nawiązujących odpowiednio do celu poznawczego i praktycznego:

Jakie są interakcyjne reguły konstruowania ładu społecznego stowarzyszenia współtworzonego w kontekście mieszanych sytuacji społecznych?

równo strategie, jak i taktyki przedstawiane są w ten sposób jednorazowo, gdy w tekście pojawiają się pierwszy raz.

W celu zachowania anonimowości imiona uczestników badania zostały zmienione bądź zastąpione pseudonimem zaproponowanym przez nich samych. Inicjały M.K. oznaczają badacza, autora publikacji. 
Jakie są z perspektywy bezdomnych trudności w procesie stowarzyszania się oraz możliwości ich pokonywania?

Celem poznawczym badania była rekonstrukcja procesu stowarzyszania się $\mathrm{w}$ kontekście mieszanych sytuacji społecznych oraz trudności $\mathrm{w}$ przebiegu tego procesu definiowane z perspektywy osób bezdomnych; celem praktycznym natomiast próba wypracowania wskazań pomocnych $\mathrm{w}$ przekraczaniu trudności $\mathrm{w}$ procesie stowarzyszania się przebiegającym w mieszanych sytuacjach społecznych.

W badaniu została zastosowana metoda generowania teorii ugruntowanej, z jej konstruktywistycznym ujęciem (Charmaz 2009), wyznaczała ona także sposób analizy gromadzonego materiału. Zastosowaną techniką była obserwacja przeżywana (Radlińska 1961) jako — w moim odczuciu - naturalna droga prowadzenia badań społecznie zaangażowanych. W naturalny sposób, bez możliwości wyodrębniania i sztucznego oddzielania od siebie, obejmuje prowadzone, regularnie powtarzane wywiady swobodne, indywidualne ( $z$ kolejnymi prezesami stowarzyszenia, bezdomnymi - mieszkańcami hostelu, „nie-bezdomnymi” członkami stowarzyszenia), wywiady grupowe $z$ mieszkańcami hostelu, obserwację uczestniczącą, udział w zebraniach, walnych zgromadzeniach, dyskusjach mieszkańców oraz analizę dokumentów, takich jak formalne pisma dotyczące działalności stowarzyszenia, korespondencja między mieszkańcami a odwoływanymi prezesami.

\section{Praca interakcyjna nad tożsamością}

Praca interakcyjna jako kategoria kluczowa $\mathrm{w}$ prezentowanej analizie na wstępie wymaga wyjaśnienia. Ma ona bogatą historię w badaniach interakcjonistów symbolicznych. Praca interakcyjna (czy też praca na poziomie interakcji) stanowiła przedmiot badań Anselma L. Straussa i współpracowników (Strauss i in. 1985), którzy koncentrowali się na warunkach leczenia pacjentów chronicznie chorych. Zaproponowali koncepcję „pracy nad trajektorią (choroby)" (trajectory work), zakładającą pracę nad zdrowiem, ale także „pracę nad ludźmi” (people work). Ta z kolei wymaga podjęcia pracy sentymentalnej, zakładającej pracę nad związanymi z trajektorią emocjami (lękiem, niepokojem, złością), co uspokaja pacjenta i włącza go w proces terapeutyczny (Goffman 2011, s. 129-132). W ramach pracy sentymentalnej wyróżnić można: pracę interakcyjną i reguły moralne (interactional work and moral rules), pracę nad zaufaniem (trust work), pracę uspokajającą (composure work), pracę nad biografią (biografical work), pracę nad tożsamością (identity work), pracę nad kontekstem świa- 
domości (awareness of context work) oraz pracę oczyszczającą (rectification work).

W przedstawianej analizie szczególnie istotna jest praca interakcyjna nad tożsamością (identity work), przez Straussa rozumiana jako praca wykonywana nad pacjentem (jego tożsamością) w celu pokonania przez niego problemów oraz odzyskania poczucia własnej wartości (Strauss i in. 1985, s. 138-139; por. Konecki 2007, s. 76).

W perspektywie symbolicznego interakcjonizmu tożsamość jednostki - aktora społecznego - najogólniej można sprowadzić do „zbioru wyobrażeń, sądów i przekonań, które konstruuje on wobec samego siebie" (Bokszański 1989, s. 12) czy też do „symbolicznej interpretacji jednostki, odnoszącej się do tego, czym jest we własnych przekonaniach i czym ma nadzieję być" (Brittan 1977, s. 102; por. Bokszański 1989, s. 13). Tożsamość postrzegana przez Straussa jako koncepcja: „[...] w całości tak nieuchwytna jak czyjeś poczucie tożsamości. Ale czymkolwiek tożsamość może być, $z$ pewnością jest ona związana $z$ nieuchronnymi oszacowaniami [appraisals] kogoś przez niego samego i przez innych" (Strauss 1969, s. 9).

Warto wspomnieć w tym miejscu, że w eksplorowanej rzeczywistości ma miejsce nie tylko podejmowana przez partnera interakcyjnego praca nad tożsamością innego, ale również podejmowana przez samego aktora — „nosiciela” tejże tożsamości — jako praca nad tożsamością własną. Przybierać może wówczas formę próby „zachowania siebie” w sytuacji, w jakiej przyszło mu żyć (Snow, Anderson 1987, s. 1336-1371). Może ujawniać się poprzez nieprzyznawanie się do innych bezdomnych czy instytucji świadczących pomoc, unikanie schronisk, dbanie o wygląd jako próbę dystansowania się od bycia zakwalifikowanym do grupy bezdomnych (szerzej zob. Kostrzyńska 2010, s. 54-68; Oliwa-Ciesielska 2004, s. 119-120; Konecki 2007, s. 78).

Przedstawię tu rekonstrukcję pracy interakcyjnej nad tożsamością podejmowanej przez bezdomnych - mieszkańców hostelu. Przeprowadzone badania ujawniły dwa wymiary (za)angażowania się mieszkańców na rzecz hostelu ${ }^{4}$ - (tymczasowego) domu, w którym przyszło im żyć. Pierwszy przybiera postać „(nic)robienia”, którego naturalną konsekwencją staje się drugi, jakim jest praca interakcyjna nad tożsamością drugiego (współmieszkańca). Prezentację rozpoczynam od „(nic)robienia”, co pozwoli le-

${ }^{4}$ Czynnikami różnicującymi poziom (za)angażowania mogą być: długość stażu w hostelu, długość trwania w bezdomności przed wprowadzeniem się do hostelu, a także utrwalone przyzwyczajenia. 
piej zrozumieć sens i celowość interakcyjnej pracy nad tożsamością współmieszkańca ${ }^{5}$.

\section{„(NIC)ROBIENIE”}

„(Nic)robienie” to kategoria odnosząca się do „procesu psychospołecznego zachodzącego $\mathrm{w}$ przestrzeni: działanie podmiotu uznającego je za sensowne i ważne w kontekście uniemożliwiającym działania alternatywne, reakcja społeczna na nie konstruowana przez podmioty jego ważność znoszące i/bądź uznające je za zagrażające" (Gulczyńska 2013, s. 88). Widoczny jest jej związek ze strukturalnie zakotwiczonymi ograniczeniami, pozostającymi nie bez znaczenia dla satysfakcjonującego sposobu organizacji codziennych aktywności.

Atmosferę „(nic)robienia” budują towarzyszące mieszkańcom „huśtawki nastrojów”, ściśle związane z pozostawaniem „bez zajęcia”, pracy, która mogłaby strukturyzować ich codzienność. „(Nic)robienie” w badanej rzeczywistości realizowane jest poprzez strategie: unikania, „niewychylania się" oraz "przegadywania życia”.

\section{Strategia unikania}

Strategia ta koncentruje się głównie na unikaniu podejmowania jakiejkolwiek pracy na rzecz hostelu („miganiu sie”) bądź na strategicznym doborze takich rodzajów pracy, które miałyby w jak najmniejszym stopniu obciążać podejmującego się jej mieszkańca. Wymówek i powodów „(nic)robienia” poprzez unikanie jest wiele: „albo skacowany, albo głowa boli, albo hemoroidy, albo cholera wie. Już tu różne rzeczy sq" (Wojtek); „albo nie wie, albo nie umie, albo mu się nie chce" (Grzegorz), dlatego strategia ta może być realizowana przez cały wachlarz taktyk, których tu przytaczam jedynie przykłady ${ }^{6}$.

Taktyka „na li s a” oznacza unikanie pracy przez zasłanianie się złym stanem zdrowia, co obrazuje poniższa wypowiedź Wojtka:

Wojtek: Jak ja wołam jednego czy drugiego do tego, co G. przywiozła, żeby podzielit to na porcje, to albo jest chory, albo się źle czuje, albo go noga boli, coś szczyka

\footnotetext{
${ }^{5}$ Kategorię „(nic)robienia” zapożyczam od Anity Gulczyńskiej (2013), która wygenerowała ją podczas badań prowadzonych nad wrastaniem społecznym młodzieży.

${ }^{6}$ Warto nakreślić rozróżnienie między opisywanymi strategiami a taktykami. Strategię rozumiem jako długofalowy plan działania, natomiast sposób, w jaki ten plan zostanie osiągnięty, określany jest jako taktyka przyporządkowana danej strategii. Strategie obejmują zbiór celów, taktyki zbiór działań prowadzących do ich realizacji.
} 
$w$ kręgostupie, albo on nie wie jak to podzielić. To ja mówię niedtugo dojdzie do tego, że tylko mordy otworzycie, a ja jeszcze wam pogryzę, będziecie tylko żuć.

Jak ujawniają powyższe wypowiedzi, stan zdrowia wielokrotnie „pogarsza się" w sytuacji konkretnego zapotrzebowania na działanie na rzecz hostelu, co w szczególny sposób denerwuje angażujących się i „nie szukających wymówek" współmieszkańców.

Taktyka „nie umiem” oznacza unikanie pracy przez zasłanianie się brakiem umiejętności. Rzeczywisty brak umiejętności w działaniach wymagających kwalifikacji spotyka się ze zrozumieniem ze strony innych. Tu jednak chodzi o sytuację, w której mieszkańcy „migają się” przed prostymi czynnościami, jak sprzątanie czy przenoszenie mebli, a także gdy ktoś unika pracy, chociaż ma odpowiednie kwalifikacje.

Taktyka „klejenia idioty” ma służyć konstruowaniu autoprezentacji „głupiego", dzięki czemu mieszkaniec może zostać odebrany jako „niezorientowany, co się dzieje", tym samym unikając pełnienia pewnych obowiązków na rzecz hostelu:

M.K.: No, ale pan nie może być też sponsorem wszystkiego.

Wojtek: No, ale co zrobię!? Jak każdy mi tu klei idiotę. Srać by chcieli, a sptuczki nie ma. No to sprzedałem szafy metalowe $i$ kupitem te sptuczki i kolanka.

Wojtek: To jest knajactwo na takim poziomie, że ...to nie takie proste. Ludzie tu się... jak mają z tego korzyść, to udają idiotów. A jak nie ma korzyści, to sa jacy sq naprawdę. To nie taka prosta sprawa.

Udawanie niezorientowania powoduje, że posługujący się opisywaną taktyką przestaje być brany pod uwagę jako potencjalny współrealizator podejmowanych działań, tym samym osiągając zamierzony cel.

Taktyka "nie dam rady, zarobiony jestem" polega na unikaniu pracy przez tłumaczenie się innymi obowiązkami poza hostelem (sprawami związanymi z organizacją zasiłku, poszukiwaniem pracy bądź jej wykonywaniem). Warto wspomnieć, że niektórzy mieszkańcy podejmowali próby weryfikacji przedstawianych „wymówek”, które — jak się okazuje jedynie w nielicznych wypadkach były uzasadnione, w pozostałych kończyło się na „zarobieniu praca, której nie ma”.

Taktyka „końca pracy” polega na ujawnianiu się dopiero pod koniec pracy, która miała być wykonana (na przykład na „przeczekaniu” w pokoju większości czasu przeznaczonego na pracę, by dołączyć do pozostałych osób, gdy jej koniec już się zbliża). Co ciekawe, taktyka ta — jak pokazuje poniższa wypowiedź Waldka - pozwala uniknąć najcięższej pracy, przy jednoczesnym „nie podpadaniu” współmieszkańcom, bo — jak mówią — „przecież coś się zrobito”. 
Waldek: Musiatbym każdemu wypierdzielić zamek i ich ruszyć. Zamkną się w pokoju $i$ udaja, że nie ma. Na samym końcu ustyszeli, że ja wynoszę jakieś śmieci. A pomóc w czymś? Teraz to możesz mnie pocatować. Mają okna otwarte to styszeli.

\section{Strategia "niewychylania się"}

W przypadku tej strategii ${ }^{7}$ dochodzi do ukrywania swojego wykształcenia, by nie zostać odebranym przez współmieszkańców jako „wymądrzający się". Jako przykład może posłużyć sytuacja, w której jeden z mieszkańców hostelu stara się ukrywać szeroką wiedzę posiadaną z racji wyższego wykształcenia i wieloletniej pracy w szkole, obawiając się, że może być ona podstawą do szykanowania.

Stanisław: Ja tu ttumaczę też... pytaja, kto to Wysocki, jak Maleńczuk śpiewał... myślatem, że żartuje, że nie wie... ale nie rozmawiam, bo żeby nie byto, że się madrzę.

Stanisław: Tam mówiono o mnie, że jestem gwiazda, że się wymądrzam... nie będę udawał, że czegoś nie wiem.... wiem...no.....inteligencja to umiejętność radzenia sobie $w$ sytuacjach życiowych, więc ja sobie nie radzę... to nie wiem, jak to jest $z$ ta moja inteligencja.

Stanisław — antycypując negatywny odbiór swojej osoby przez współmieszkańców - decyduje się nie ujawniać wiedzy czy umiejętności, tym samym chroni siebie przed potencjalną stygmatyzacją.

\section{Strategia "przegadywania życia”}

„Przegadywanie życia” polega na wypełnianiu codzienności plotkami, opowieściami z przeszłości, „karmieniu się” wspomnieniami. Bezczynność - jak mówią — rodzi plotki, które aranżują i urozmaicają życie wewnętrzne hostelu. Ważnym elementem stają się wspomnienia, z jednej strony pomagają przetrwać, gdy sięgają czasów, do których warto wracać, z drugiej zaś - uderzając w drażliwe struny relacji z rodziną czy problemów z nałogami, powiększają rozżalenie i gorycz z powodu sytuacji, w jakiej przyszło żyć. „Karmienie się” wspomnieniami czy plotkami, niekiedy w niekontrolowany sposób wypełniając codzienność, może zabierać miejsce innym aktywnościom, co sprawia, że życie w hostelu może sprzyjać atmosferze marazmu i realizowania pustej gry słownej, która sprowadza się do obie-

7 Strategia ta bliska jest taktyce tłumacza opisanej niżej jako element strategii perswazji uruchamianej przez poczucie współodpowiedzialności za miejsce. Dotyczy również mieszkańców dysponujących wiedzą z racji wyższego wykształcenia, lecz tam wiedzę wykorzystuje się do objaśniania rzeczywistości współmieszkańcom. 
cywania światu, a może przede wszystkim samemu sobie, chwilową w nim obecność. Rozciąga się to w czasie za sprawą coraz to innych usprawiedliwień. Wówczas hostel przyjmuje raczej formę „przechowalni”, niż miejsca motywującego do zmian.

Wojtek: Rodza się plotki. Przychodza wspomnienia, lepsze, gorsze. Tak się karmimy. Też widzimy - jest ten świat, gdzie ludzie maja inne problemy, często $i$ większe. To nie oszukujmy się — jest poczucie, że... no jedni chca się tu urzadzić, nie widza możliwości wyrwania się. Nawet jak o tym gadaja, to tylko gadaja. Ja i tak wiem, że nic $z$ tego nie będzie.

„Karmienie się” wspomnieniami, zaangażowanie w plotki, odczucie, że życie toczy się gdzieś obok, poza nimi — to wszystko buduje atmosferę być może pozwalającą przetrwać przez krótki czas, jednak przedłużając się, przynosi poczucie „stłamszenia” i „przyduszenia”. Towarzyszy temu wstyd odczuwany przez mieszkańców hostelu w związku z sytuacją „utkwienia” na takim a nie innym etapie życia. To odczucie niemocy, braku możliwości wypełniania zinternalizowanych wcześniej norm (wzorców) obowiązujących w społeczeństwie (Giddens 2001, s. 94-95; Rakowski 2009, s. 150 -151) wiąże się z odczuciem niedostatku, nieadekwatności, a tym samym wywołuje wstyd.

\section{Przyczyny "(nic)robienia”}

W podsumowaniu zjawiska „(nic)robienia” warto wyodrębnić jego przyczyny wskazywane przez uczestników badania. Wyróżniają trzy podstawowe. Pierwszą jest lenistwo, czy inaczej „nygusostwo”. To — jak opisują — niechęć do robienia czegokolwiek, bierność w podejmowaniu jakichkolwiek działań, na co wskazuje poniższy dialog.

Zbyszek: Na razie każdy ma gdzieś. Nie wiem na co oni czekaja, na cud...

Rafał: taa, na zbawienie. Albo na przyjście kolejnego mesjasza chyba.

M.K.: No ale to wszyscy? Przecież są chyba osoby, które coś jeszcze robią?

Zbyszek: ...taa, pod siebie. Pani Gosiu, to sa ludzie...

Rafał: Potowa to sa nygusy albo lenie...

Zbyszek: Siedzieć cały dzień, leżeć i czekać aż mu z nieba spadnie...

Rafał: ...no allah mu da.... No niestety tak jest.

Kolejną przyczyną „(nic)robienia” według uczestników badania jest zainteresowanie własną osobą, posiadanie „swojego świata”, w którym brak miejsca na działanie na rzecz hostelu, w którym - chwilowo czy na dłużej przyszło żyć. Wypowiedzi Marka i Wojtka ujawniają ponadto przypisywanie „(nic)robiącym” przeważającego zainteresowania zaspokojeniem potrzeb życiowych wynikających z uzależnienia: 
Marek: Tu nie ma chętnych do działania. Niektórzy...wyspać się, jak ma to kielicha wypić... B16 ${ }^{8} i$ to go interesuje. Oni się nie właczaja... świat maja, interesuje go wokót siebie tylko.

Wojtek: Albo pokazuja tam zasrany kibel. Niektórzy używaja gazet. 60 groszy papier kosztuje. Na wódkę maja, na to nie mają. Ale tu już widzę, że weszło takie rozumowanie, że ktoś ma na alkohol albo na jakieś zbytki, a później oszczędza na papierze toaletowym, co jest irytujace dla $z$ kolei innych.

Ostatnią z wymienianych przez uczestników badania przyczyn „(nic)robienia” jest przyzwyczajenie do zaistniałej sytuacji, co po raz kolejny sprowadza się do obniżenia poziomu życia przez zaspokajanie jedynie najbardziej podstawowych potrzeb pozwalających na przetrwanie. Jak twierdzi Marek: „nauczyt się tak... lepiej uwalić się i leżeć”. Stają się zatem „meliorantami” — jak opisuje jeden z mieszkańców hostelu, Stefan gotowymi zaakceptować wszystko, bez walki z zastaną rzeczywistością:

Stefan: Stare capy po 50 lat maja i nie wiedza, co potrzebne im jest do życia? Jak się przyzwyczaili jak melioranty. Nawet nie sa $w$ stanie uprać. No przecież niech pani zobaczy po tych pokojach, jak oni śpia. Wersalka - syf trypla gania, koc brudny, prześmierdny i on się na tym kładzie, on się tym przykrywa. To się zastanawiam, czy oni od dziecka mieli mieszkania swoje. Wszedtem do pokoju, mówię: czemu macie zamknięte okno, przecież tu śmierdzi, jakby matpe rozerwało. Jest upat na dworze i nie otworzysz nawet tego okna. Firanki nie wypierzesz.

Jednocześnie warto wspomnieć ocenę opisywanej sytuacji wyrażoną przez osobę spoza hostelu, współpracującego z nim pracownika socjalnego. Według niego „(nic)robienie” wewnątrz hostelu ściśle łączy się z niepodejmowaniem działań na zewnątrz, chociażby w postaci poszukiwania pracy. „Nie podejmuje się, bo tak jest wygodniej”, jak twierdzi, próbując zrozumieć fakt, iż dawniej udawało im się znaleźć pracę, natomiast aktualnie, kiedy zostali otoczeni opieką w postaci zasiłków, jest z tym znacznie trudniej.

Pracownik socjalny: Chyba jakaś praca gdzieś zawszejest. Żaden nie ma pracy żadnej? Przedtem mieliście jakieś na czarno prace, a teraz żaden nie ma pracy, niczego?

\section{INTERAKCYJNA PRACA NAD TOŻSAMOŚCIĄ}

Odpowiedzią niektórych mieszkańców hostelu na opisane wyżej „(nic)robienie" jest podejmowana przez nich interakcyjna praca nad tożsa-

${ }^{8}$ B16 to potoczne określenie napojów „alkoholopodobnych” — rozmaitych mieszanek chemicznych zazwyczaj z niewielką domieszką czystego alkoholu (rozpuszczalnik, rozpałka do grilla), popularnych wśród bezdomnych z racji niewielkich kosztów — jak mówią: „kasa mała, a efekt ten sam". 
mością drugiego. Twierdzą, że stanowi ona wyraz współodpowiedzialności za miejsce, w którym przyszło im żyć. Jest to zarówno „poczuwanie się”, „bycie odpowiedzialnym” za miejsce rozumiane jako „dach nad głowa”, jak i element roli współmieszkańca, z której wynika dbałość o komfort pobytu w hostelu:

Grzegorz: No to przepraszam...albo się ktoś poczuwa i czuje się tak samo odpowiedzialny i przyjdzie rano i powie na przykład: stuchaj Stanisław, dzisiaj mam czas, to mogę polatać, coś załatwić.

Można mówić tu o konkretnych działaniach w trosce o hostel jako „zastępczy dom”, co zawsze pośrednio wiąże się z aktywnością na rzecz współmieszkańców. Mam jednak na myśli raczej (za)angażowanie w sferze relacyjnej, które za badanymi nazwałam wzajemnym „wychowywaniem się". Niejednokrotnie nie przebiega ono w sposób całkiem klarowny dla adresata - w formie „zarzucania sidet”, „budowania podstępów” czy „prowokacji w celach wychowawczych", jak zwykli opisywać te działania ich sprawcy. W zależności od rodzaju ingerencji „wychowywanie” drugiego może być realizowane za pomocą strategii: radykalnej lub opartej na perswazji.

\section{Strategie radykalne}

Zakładają „ostre” działania, które — zdaniem mieszkańców hostelu mają ,potrzasnaćc", prowadząc do zmiany zachowania ich adresata. Można tu wyróżnić taktyki trzech rodzajów.

Taktyka „przetrzymania” (,brania na przeczekanie”) stanowi próbę sprostania specyfice charakterologicznej mieszkańców, która sprzyja „cwaniactwu", czyli - jak wyjaśniają badani — zadbaniu przede wszystkim o samego siebie, niekiedy kosztem drugiego. Przykładem może być „udawanie głupiego, niezorientowanego, zdziwionego, bo tak wygodniej”, co dla niektórych staje się sposobem na uniknięcie obowiązków, na przykład konieczności „wykupywania pradu”. Nagminnie ma to miejsce w hostelu w postaci „podczepiania się” w formie przeczekania, „przekoczowania jak jaskiniowcy, bo $w$ końcu któryś zmięknie i kupi", a wiadomo, że wykupi, bo sam potrzebuje „żyć normalnie”. Zazwyczaj w takich sytuacjach pozostali „licza, że kolejny raz wykorzystać się da Młody [jeden ze współmieszkańców - M.K.]", jako ten, któremu (z racji różnicy wieku) wypada się wkupić, zadbać o pozostałych. Kiedy na liczniku pusto uruchamia się taktykę „przetrzymania”, zaczyna się „udawanie głupa” - „jak to szybko się skończyło” i znowu nie ma prądu, co opisuje Waldek: 
Ja też nie jestem krowa dojna, żeby za wszystkich płacić. A mówiq, ooo młody leć kup. Ale, ja też chcę normalnie żyć. Teraz to biorę na przeczekanie. Mam pieniądze, ale nie.. Kończy się prąd $i$ wiadomo...przychodzi...zbawiciel.

Taktyka „przetrzymania” przyjmuje formę strategicznego, celowego zaniechania, co ma zmusić do zaangażowania się osoby wpisujące się w kategorię „cwaniaków”.

Taktyka „straszaka” polega na próbie zmotywowania współmieszkańca do zmiany postępowania poprzez nastraszenie go wyimaginowanymi negatywnymi konsekwencjami jego postępowania, często związanymi $\mathrm{z}$ planami usunięcia go $\mathrm{z}$ hostelu przez zarząd:

Marek: Kiedyś postraszyłem Lutka, mówię: stuchaj, byto zebranie, na które nie dotarteś $i$ głosowaliśmy tajnie nad tym, czy twoja postawa zasługuje na to, żebyś tu $z$ nami przebywat. No $i$ byto bardzo źle dla ciebie. $Z 12$ osób 8 się opowiedziało za tym, żebyś zostat stąd wyrzucony. Ale serio to wziąt. Ja tego nie prostowałem bardzo dtugo. Byt przerażony, nie wiedział czy tu wracać. Od A. się nauczyłem.

Taktyka „założenia szlabanu” polega na świadomym i strategicznym nieudzieleniu pomocy, by tym samym zmobilizować współmieszkańca do działania. Podejmujący taką aktywność pozostaje czujny wobec partnera, aby przypadkowo nie doprowadzić do reakcji innej niż zakładana:

Wojtek: No to nie pasuje, żeby ja jem, a on głodny leży. Mówię Norbert chodź wstań, zrobimy pierogi razem. Jak nie miat już co, a mu zatożytem raz szlaban, no to se wyszedł na śmieci, nazbierat jedzenia.

\section{Strategie oparte na perswazji}

Strategie oparte na perswazji zakładają mniejszą ingerencję i radykalizm działania. Wyróżnić można taktyki czterech rodzajów.

Taktyka odwołania się do przeszłości ma służyć zmotywowaniu mieszkańców do większego zaangażowania się w prace na rzecz hostelu. Opiera się na odwoływaniu się do doświadczeń z przeszłości (sprzed bezdomności), związanych z dbaniem o własny dom czy mieszkanie.

Wojtek: Czasem to się zastanawiam, czy ci ludzie w ogóle od urodzenia mieli jakieś mieszkania. No korzystaja z jednej łazienki, żaden nie weźmie mopa, żeby zetrzeć, tylko po kolana woda, to by może jakoś przeszedt i nie zetrze.

Opisywana taktyka może okazać się bezskuteczna co najmniej z dwóch przyczyn. Pierwsza to napięcie interakcyjne $w$ komunikacji z porywczym współmieszkańcem, który szczególną uwagę przykłada do „wychowywania” drugiego. 
Grzegorz: Tutaj powinien Wojtek tym ludziom wszystko tłumaczyć na spokojnie, a on nie...on to jest tak nerwowy, że on to od razu na kurwa mać i na zasadzie przymusu...ja ci mówię, masz tak zrobić $i$ tyle.

Drugą przyczyną mogą być zaburzenia w komunikacji dotyczącej toczących się wokół przemian związanych ze zmianą rządów w organizacji prowadzącej hostel.

Grzegorz: Oni nie rozumieja, to co dzisiaj pan powiedziat na spotkaniu: „Wy jesteście władza, to jest wasze stowarzyszenie". A wszyscy maja wrażenie, tyle że nie wiem czyje, a mnie się należy, bo tu jestem. A tak naprawdę się nikomu nic nie należy. Nic nie masz za darmo.

Taktyka tłumacza jest podejmowana przez mieszkańców posiadających status „madrego" (czyli tego z ,jakimś” wykształceniem, „po szkołach” lub po prostu używającego nie wszystkim znanego słownictwa). Tłumaczeniu, objaśnianiu podlegają rozmaite kwestie, na przykład przebieg walnego zgromadzenia, ma to służyć podniesieniu świadomości innych mieszkańców hostelu, co do podejmowanych działań.

Wojtek: Raz zrozumieją, potem okaże się, że nie zrozumieli. Tutaj nie da się żadnej idei wprowadzić od początku do końca. Poza ta, gdzie bierze się bata i mówi: nosić. Teraz ttumaczę jak mogę. Czasem jest opór taki... nie opór intelektualny, ale innego rodzaju — że nie ma z tego korzyści.

Marek: A ostatnio podpisaliśmy tą umowę o świadczeniach. Ale nie wszyscy rozumieja, stąd niecierpliwość albo niechęć do angażowania się, bo nie wiedza, o co chodzi. Tu trzeba używać szczególnego języka. Tłumaczyć z polskiego na nasze. I oczywiście się też boja.

Warto podkreślić, że niekiedy ten, kto rozumie więcej, ma jakby szczególną władzę nad pozostałymi. Patent tłumacza powoduje, że staje się także posiadaczem nieograniczonej wolności w tym, komu, kiedy i w jakim zakresie będzie tłumaczyć procesy zmian ${ }^{9}$. Dlatego czasem dochodzi do wykorzystania posiadanej wiedzy i umiejętności, czyli manipulowania drugim w celu osiągnięcia zysków indywidualnych. Wiedza staje się wówczas kartą przetargową, służy stygmatyzacji wewnętrznej „lepszego”, bo „mądrzejszego" od drugiego z piętnem „nierozumienia”.

Taktyka własnego przykładu ma zmotywować mieszkańców hostelu do (za)angażowania się. Polega na tym, że obserwując czyjeś (za)angażowanie $\mathrm{w}$ działanie, przyłączają się do niego. Nie znajdują wówczas

9 Chodzi tu zwłaszcza o działania oparte na interakcjach z „obcymi” spoza hostelu, obejmujące szereg formalnych posunięć, dokumentów, rozmów z osobami decyzyjnymi, co niejednokrotnie wydaje się „przerastać” „zwykłego” mieszkańca. 
pretekstu do „wymigiwania się”. Taki sposób „wychowywania” praktykujący go mieszkańcy określają jako "motywujące działanie innych” czy inaczej — „zarażanie działaniem”:

Zbyszek: Będziemy kombinować, no będziemy kombinować.

Rafał: Pan Zbyszek to ma tyle chęci, że czasami mnie zaraża tymi chęciami.

Zbyszek: Widza, że człowiek się rusza, to się dołączają. Ktoś pyta: mogę przyjść do was odwiedzić? Nie, remont mamy. Dwa lata macie remont? Taa, to sa renciści, jedna osoba pracuje [śmiech].

Taktyka "zrobię sam” stosowana jest przede wszystkim przez wspomnianego wyżej wyjątkowo (za)angażowanego współmieszkańca. Ponieważ zauważa brak zaangażowania innych, ale i wobec niewiary $\mathrm{w}$ ich kompetencje - sam zaczyna wykonywać większość działań. Sytuacja ta wywołuje u niego poczucie osamotnienia. Czuje się „przytłoczony” różnorodnością i wielością „spraw do załatwienia”, co — jak się wydaje — stanowi rezultat stygmatyzacji wewnętrznej w postaci uznania współmieszkańców za osoby słabsze, mniej zorientowane, tym samym pozbawione możliwości włączenia się w podejmowane działania. Działa samodzielnie, bo jak twierdzi — „sam zrobi to lepiej”. Sytuacja ta z czasem utrwala się według logiki błędnego koła: ze strony mieszkańców powtarzają się działania utrwalające stygmat nadany im przez przywódcę, u niego zaś potwierdzające słuszność osamotnionego działania, skoro ma do czynienia $z$ "takimi” mieszkańcami.

Omawiając działania służące wzajemnemu „wychowywaniu się” mieszkańców, warto zastanowić się nad ukrytymi celami ich podejmowania. Może to odsłonić oczekiwania mieszkańców co do współdziałania jako warunku utrzymania się i przetrwania w hostelu. Albowiem podejmowane próby „wychowywania się” zmierzają raczej do zapewnienia sobie przetrwania, polepszenia warunków bytu, niż są próbą wywołania trwałych zmian u mieszkańców w trosce o nich.

Jednocześnie można sądzić, że „wychowywaniu się” sprzyja atmosfera małej grupy osób przebywających w hostelu. Widoczne są zwłaszcza przejawy troski o drugiego w obrębie poszczególnych pokoi. Jak twierdzą mieszkańcy, w pokojach tworzą się „małe wspólnoty”, czego nie można dostrzec w skali wszystkich mieszkańców.

Marek: My tu pokojami się trzymamy, we trzech jesteśmy razem.

Stefan: Pomaga mi tu bardzo Pawet z pokoju, zjedzeniem gotuje więcej, daje przeżyć.

Zbyszek: Jak tu jest biedny, tu taki byt, co mieszkał ze mna. No to nie pasuje, żebym ja jadt, a on głodny leży. 
Doskonałą ilustracją podejmowania prób pomagania sobie nawzajem są słowa jednego z mieszkańców, Zbyszka, proponującego pomoc poruszającemu się na wózku inwalidzkim, by mógł on pokonać schody dzielące go od pomieszczenia, w którym za chwilę ma rozpocząć się walne zgromadzenie, choć ten już zrezygnował z uczestnictwa ze względu na swoje ograniczenie.

Zbyszek: Nie walcz sam ze soba, bo sam tu nie jesteś. Zobacz ile tu chłopa. Zaraz cie na plecach zaniesiemy. Pasy zapiać $i$ jedziemy.

\section{ZAKOŃCZENIE, CZYLI O „WĄTPLIWYCH” SKUTKACH INTERAKCYJNEJ PRACY NAD ZMIANĄ TOŻSAMOŚCI DRUGIEGO}

Mieszkańcy podejmujący interakcyjną pracę nad tożsamością drugiego zwracają uwagę na duże trudności w ich działaniu, polegającym na próbie „zmiany przyzwyczajen" człowieka, który przez większą część życia przystosował się do zupełnie innego trybu funkcjonowania, ponieważ hostel stanowi „zbieraninę” tego typu osób.

Marek: Jedni tam mają chęci, inni nie. Zbieranina różnych charakterów. Jednemu tak życie pasuje, drugiemu tak. Trzeba się przystosować, bo co zrobić. Starego chłopa co $\dot{z} y t$ pót życia $w$ warunkach takich, to się go już do niczego nie nauczy. Będzie już jaki jest. Przejść do porządku dziennego i już.

Perspektywa zewnętrzna, osoby współpracującej z mieszkańcami, potwierdza, jak się wydaje, opisywaną przez Marka trudność, a zatem brak wspólnej odpowiedzialności za miejsce:

Współpracownik stowarzyszenia: Oni tego nie umieja i przede wszystkim tam wszyscy w hostelu nie mają poczucia odpowiedzialności za to. To ich wspólna sprawa. Każdy człowiek, nie ten tylko $z$ hostelu, każdy czlowiek ma jakieś problemy $i$ każdy człowiek musi podejmować decyzje i ponosić za nie odpowiedzialność. Natomiast oni czuja się zwolnieni z tej odpowiedzialności. Nie maja pieniędzy na czynsz, na te media, no to nie maja. I oni nie widza problemu.

Jednocześnie mieszkańcy wskazują konkretne, w ich opinii „wątpliwe” skutki „wychowywania się”. Pierwszym jest to, co określają mianem „odrastania dupy", czyli szybkie zapominanie o otrzymanym wsparciu. Wspierani nie tylko nie przekazują go dalej (co jest znaczące dla wspierających), ale i zapominają o wyrazie wdzięczności. „Odrastanie dupy” to najczęstszy efekt udzielenia pomocy - odwracania się od pomagającego. Jak twierdzi między innymi Wojtek, nawet jeśli na początku jest wdzięczność, w rezultacie i tak kończy się podobnie: 
Wojtek: Ale nie, bo to poprzewracało się we tbie. Jak nie miat nic i nositem mu tam $z$ litości coś do jedzenia, to byt do rany przytóż... A teraz załapałeś jakieś parę groszy i burżuja tniesz, do niczego się nie poczuwasz... popieprzyło mu się w dupie, dupa odrosta.

Kolejnym niepowodzeniem w pracy interakcyjnej nad tożsamością drugiego może być „wykorzystanie zwierzen”, czyli użycie uzyskanych informacji, często intymnych i ważnych dla rozmówcy, przeciwko niemu, chociażby jako przejaw występującego $\mathrm{w}$ tym środowisku donosicielstwa. Zjawisko to jest wykorzystywane przez kolejnych kierowników hostelu jako jedna ze strategii rządzenia, a także przez pracowników socjalnych do „diagnozowania” środowiska w celu podjęcia decyzji o przyznaniu zasiłku (chodzi tu zwłaszcza o informacje dotyczące podejmowanej przez mieszkańców hostelu pracy „na czarno”).

Niekiedy w relacjach opartych na „wychowywaniu się” ujawnia się także „udawanie” przed sobą nawzajem czy „zapożyczanie historii” zasłyszanych od innych i przedstawianie ich jako swoich (zob. Kostrzyńska 2018), co wskazuje na podejrzany kontekst świadomościowy opisywanych interakcji (Glaser, Strauss 1964).

Ostatnim już „wattpliwym” skutkiem opisywanej pracy interakcyjnej nad tożsamością drugiego jest obawa przed nawiązaniem zbyt bliskich relacji, które po „wyjściu z hostelu mogłyby powlec się” za konkretnym „wychowujacym”, stając mu na drodze powrotu do „normalności”, chyba że - jak podkreślają mieszkańcy - pomoc byłaby wówczas udzielana już na innych zasadach, z pozycji „zewnętrznego filantropa”. Jednocześnie lepiej jest "nie urywać kontaktów” zupełnie, bo nigdy nie wiadomo, kiedy dana znajomość może się jeszcze przydać. Tak czy inaczej — jak podkreśla Wojtek „w tym środowisku lepiej nie mieć zobowiąañ”:

Wojtek: To mnie też irytuje. Jak się wali to nigdy nie ma tych osób. A jak im bieda, to ja zawsze do pomocy. Ja nie mam żadnych zobowiazań wobec tych ludzi. Dlaczego do mnie? Ja mam petne prawo do asertywności. Nic mi nie grozi... zerwanie kontaktów. Ja to się boję, że jak kiedyśs stąd wyjdę, to żeby się nie powlokło... w stosunku do niektórych osób tak, oczywiście. Zresztą nie chciałbym zrywać kompletnie kontaktów, może znajdę się w sytuacji, że będę mógt pomóc... to wtedy jak ten szlachetny filantrop z zewnatrz, bo to trochę inaczej wyglada, a nie jako bezdomny. Ale ja sobie nie wyobrażam tych wizyt w swoim mieszkaniu prywatnym. A po co? Wódki sie napić nie mogę z kimś takim, czy innego trunku, bo tutaj jest zakaz. To będę się czut odpowiedzialny za to, że zostat wywalony, tak?

Podsumowując spostrzeżenia dotyczące pracy interakcyjnej nad zmianą tożsamości drugiego, podejmowaną $\mathrm{w}$ ramach (za)angażowania się w działania na rzecz odpowiedzialności za miejsce (hostel oraz współ- 
mieszkańców), należy podkreślić, że wszelkie takie działania mieszkańców hostelu koncentrują się wokół dwóch podstawowych celów. Po pierwsze, chodzi o (za)angażowanie rozumiane jako udział w sprawie (działania dotyczące funkcjonowania hostelu, dbałości o współmieszkańca). Po drugie, ważne jest (za)angażowanie wyrażające się w jakości wkładu w prace organizacyjne na rzecz samego hostelu ${ }^{10}$. Podejmowane przez mieszkańców hostelu działania, przyjmujące charakter pracy nad tożsamością (Strauss i in. 1985), przez sprawne manewrowanie tożsamościami sytuacyjnymi zmierzają do kreowania obrazu społecznego jednostki zgodnej z oczekiwaniami współmieszkańców.

\section{BIBLIOGRAFIA}

Blumer Herbert, 1984, Społeczeństwo jako symboliczna interakcja, tłum. Grażyna Woroniecka, w: Edmund Mokrzycki (red.), Kryzys $i$ schizma, t. 1: Antyscjentystyczne tendencje w socjologii wspótczesnej, Państwowy Instytut Wydawniczy, Warszawa, s. 71-86.

Blumer Herbert, 2007, Interakcjonizm symboliczny: perspektywa i metoda, tłum. Grażyna Woroniecka, Nomos, Kraków.

Błeszyńska Katarzyna, 2001, Niepetnosprawność a struktura identyfikacji społecznych, Wydawnictwo Akademickie Żak, Warszawa.

Bokszański Zbigniew, 1989, Tożsamość, interakcja, grupa. Tożsamość jednostki w perspektywie teorii socjologicznej, Wydawnictwo Uniwersytetu Łódzkiego, Łódź.

Brittan Arthur, 1977, The Privatised World, Routledge and Kegan Paul, London.

Charmaz Kathy, 2009, Teoria ugruntowana. Praktyczny przewodnik po analizie jakościowej, tłum. Barbara Komorowska, Wydawnictwo Naukowe PWN, Warszawa.

Giddens Anthony, 2001, Nowe zasady metody socjologicznej. Pozytywna krytyka socjologii interpretatywnych, tłum. Grażyna Woroniecka, Nomos, Kraków.

Glaser Barney G., Strauss Anselm L., 1964, Awareness Contexts and Social Interaction, „American Sociological Review", t. 29(5), s. 669-679.

Glaser Barney G., Strauss Anselm L., 2006, Konteksty świadomości i interakcja społeczna, w: Aleksandra Jasińska-Kania, Lech M. Nijakowski, Jerzy Szacki, Marek Ziółkowski (red.), Wspótczesne teorie socjologiczne, Scholar, Warszawa.

Glaser Barney G., Strauss Anselm L., 2009 [1967], Odkrywanie teorii gruntowanej. Strategie badania jakościowego, tłum. Marek Gorzko, Nomos, Kraków.

Goffman Erving, 2000, Człowiek $w$ teatrze życia codziennego, tłum. Helena Datner-Śpiewak, Paweł Śpiewak, Wydawnictwo KR, Warszawa.

Goffman Erving, 2005, Piętno. Rozważania o zranionej tożsamości, tłum. Aleksandra Dzierżyński, Joanna Tokarska-Bakir, Gdańskie Wydawnictwo Psychologiczne, Gdańsk.

Goffman Erving, 2006, Rytuat interakcyjny, tłum. Anna Szulżycka, Wydawnictwo Naukowe PWN, Warszawa.

10 Wsparcie współmieszkańców podlega specjalizacji, której przykładem może być podjęcie przez jednego mieszkańca hostelu, z własnej inicjatywy, współpracy z rodziną współlokatora, by ustalić jednolitą strategię pomocy. 
Goffman Erving, 2011, Instytucje totalne. O pacjentach szpitali psychiatrycznych i mieszkancach innych instytucji totalnych, tłum. Olena Waśkiewicz, Jacek Łaszcz, Gdańskie Wydawnictwo Psychologiczne, Sopot.

Granosik Mariusz, 2006, Profesjonalny wymiar pracy socjalnej, Biblioteka Pracownika Socjalnego, Katowice.

Gulczyńska Anita, 2013, „Chłopaki z dzielnicy”. Studium społeczno-pedagogiczne z perspektywy interakcyjnej, Wydawnictwo Uniwersytetu Łódzkiego, Łódź.

Hewitt John P., 1976, Self and Society: A Symbolic Interactionist Social Psychology, Allyn and Bacon, Boston.

Konecki Krzysztof T., 2007, Procesualne ujęcie organizacji. Organizacje, struktury, procesy $i$ tożsamości, w: Krzysztof T. Konecki, Piotr Chomczyński (red.), Zarzadzanie organizacjami. Organizacja jako proces, Wydawnictwo Uniwersytetu Łódzkiego, Łódź.

Kostrzyńska Małgorzata, 2010, W jaki sposób świat „obcych” staje się światem „swoich”?. „Praca Socjalna", nr 4, s. 54-68.

Kostrzyńska Małgorzata, 2018, Stowarzyszanie się „wykluczonych”. Przykład bezdomności, Wydawnictwo Uniwersytetu Łódzkiego, Łódź.

Łukowski Wojciech, 2012, Partycypacja, czyli o trudnościach $w$ dzieleniu się władza, „Zoon Politikon", nr 3, s. 33-52.

Melchior Małgorzata, 1990, Społeczna tożsamość jednostki, Uniwersytet Warszawski, Warszawa.

Oliwa-Ciesielska Monika, 2004, Piętno nieprzypisania. Studium o wyizolowaniu bezdomnych, Wydawnictwo Naukowe UAM, Poznań.

Radlińska Helena, 1961, Pedagogika społeczna, Ossolineum, Warszawa.

Rakowski Tomasz, 2009, Łowcy, zbieracze, praktycy niemocy. Etnografia człowieka zdegradowanego, słowo/obraz terytoria, Gdańsk.

Snow David A., Anderson Leon, 1987, Identity Work Among the Homeless: The Verbal Construction and Avowal of Personal Identities, „American Journal of Sociology”, t. 92(6), s. 1336-1371.

Strauss Anselm L., 2013 [1969], Zwierciadła i maski. W poszukiwaniu tożsamości, tłum. Agnieszka Hałas. Nomos, Kraków.

Strauss Anselm L., Fagerhaugh Shizuko, Suczek Barbara, Wiener Carolyn L., 1985, Social Organization of Medical Work, The University of Chicago Press. Chicago.

Wujcicka Małgorzata, 2008, „Przeszkody w procesie włączania społecznego bezdomnych mężczyzn z perspektywy badanych", niepublikowana praca magisterska, biblioteka Wydziału Nauk o Wychowaniu UŁ.

\title{
INTERACTIVE WORK ON ONE ANOTHER'S IDENTITIES: ON THE MUTUAL “EDUCATION” TACTICS OF HOMELESS PEOPLE
}

\author{
Małgorzata Kostrzyńska \\ (University of Lodz)
}

\section{Abstract}

This article contains a partial report on ethnographic research conducted among homeless people who live in the streets outside the system of institutional 
aid or are staying in a hostel they created themselves. The study, carried out according to the principles of an interpretive orientation, created an opportunity to learn the views of the homeless people. It describes manifestations of engagement on behalf of the hostel in which they live and of a special type of work they undertake-interactive work on one another's identity, which they refer to as mutual "education"-as well as involvement in the form of "doing nothing."

Key words: identity, homelessness, identity work, symbolic interactionism

Stowa kluczowe: tożsamość, bezdomność, praca interakcyjna, interakcjonizm symboliczny 